\title{
Development and testing of a novel steel formwork for casting concrete slabs with different sizes
}

\author{
Desarrollo y ensayo de un nuevo molde en acero para fundir losas de \\ concreto con diferentes tamaños
}

\author{
Desenvolvimento e ensaio de um novo molde em aço para fundir lajes \\ de concreto com diferentes tamanhos
}

Fecha de recepción: 10 de marzo de 2017

Fecha de aceptación: 1 de agosto de 2017

\author{
Julián Carrillo* \\ Felipe A. Riveros* \\ Luis E. Llano**t
}

\section{Abstract}

This paper describes and discusses the results of designing and implementing a steel formwork for casting and testing concrete slab specimens with different sizes. The formwork saves space, materials and costs due to the different configurations it may adopt, which allow, for instance, casting slabs with different sizes. The formwork avoids purchasing a greater number of formworks of particular dimensions, which increases costs and the space needed for storage. The formwork performance was assessed through the analysis of numerical results (strain and stress) obtained from simulations using finite element software. Performance was also verified during construction and testing of concrete slab specimens, reinforced with welded-wire meshes or steel fibers. The novel steel formwork herein presented and discussed is currently a patent pending in the Colombian Office of Industry and Commerce.

Keywords: Concrete mold; Concrete slab; Energy absorption test; FEM; Fiber reinforced concrete; Flexural test; Slab-on-ground; Steel formwork.

\section{Resumen}

Se describen y discuten los resultados del diseño y la implementación de una formaleta de acero para fundir y ensayar especímenes de losas de concreto con diferente geometría. La formaleta permite ahorrar espacio, materiales y costo, debido a sus diferentes posibles configuraciones; por ejemplo, permite fundir losas de diferentes tamaños. La formaleta evita adquirir otras con dimensiones específicas, lo cual implica mayores costos y mayor espacio para almacenamiento. La evaluación del desempeño de la formaleta se llevó a cabo a partir del análisis de resultados numéricos (deformación y esfuerzo) obtenidos de simulaciones con software de elementos finitos. El desempeño también se verificó durante la construcción y ensayo de especímenes de losas de concreto reforzadas con mallas electro-soldadas o fibras de acero. El nuevo molde en acero aquí presentado y discutido está actualmente en proceso de patente en la Superintendencia de Industria y Comercio de Colombia.

* Ph.D. Universidad Militar Nueva Granada (Bogotá D.C, Colombia). wilmer.carrillo@unimilitar.edu.co. ORCID: 0000-0002-8274-5414.

** Universidad Militar Nueva Granada (Bogotá D.C, Colombia). estructuras.sismica@unimilitar.edu.co.

*** M.Sc. Universidad Militar Nueva Granada (Bogotá D.C, Colombia). luis.llano@unimilitar.edu.co. 
Palabras clave: Concreto reforzado con fibras; Ensayo a flexión; Ensayo de absorción de energía; Equipos de ensayo; FEM; Formaleta de acero; Losa de concreto; Losa sobre terreno; Molde de concreto.

\section{Resumo}

Descrevem-se e discutem-se os resultados do desenho e a implementação de um molde de aço para fundir e ensaiar espécimes de lajes de concreto com diferente geometria. O molde permite economizar espaço, materiais e custo, devido a suas diferentes possíveis configurações; por exemplo, permite fundir lajes de diferentes tamanhos. O molde evita adquirir outros com dimensões específicas, o que implica maiores custos e maior espaço para armazenamento. A avaliação do desempenho do molde foi realizada a partir da análise de resultados numéricos (deformação e esforço) obtidos de simulações com software de elementos finitos. O desempenho também foi verificado durante a construção e ensaio de espécimes de lajes de concreto reforçadas com redes eletro-soldadas ou fibras de aço. O novo molde em aço aqui apresentado e discutido está atualmente em processo de patente na Superintendência da Indústria e Comércio da Colômbia.

Palavras chave: Concreto reforçado com fibras; Ensaio a flexão; Ensaio de absorção de energia; Equipamentos de ensaio; FEM; Laje de concreto, Laje sobre terreno; Molde de aço; Molde de concreto. 


\section{INTRODUCTION}

Construction progress experienced by cities is continuously growing; hence, more efficient procedures are required to save time and money and to increase the reliability of the products. Therefore, laboratory tests that allow to experimentally observe and validate the performance of materials, systems, and structures should be performed during experimental studies [1]. Particular elements for manufacturing concrete specimens are required for executing these experimental programs, i.e., molds or steel formworks. However, the bad quality of the formwork is one of the major sources of poor quality concrete, which subsequently leads to the deterioration of concrete structures [2].

Currently, a large number of companies distribute elements and accessories for testing materials and structures. These companies have large portfolios with alternatives for institutes and universities that carry out teaching, research, and/or extension activities related to laboratory tests for materials and structures. Most of these solutions are expensive and aimed at a particular activity. For example, in the case of the steel formwork used for casting specimens such as beams or cylinder of standard dimensions, most of them have a configuration that allows casting only one particular shape and size of the concrete specimen.

This paper describes and discusses the design and implementation of a steel formwork to cast and test concrete slab specimens. The formwork performance was assessed through the analysis of numerical and experimental results that were obtained from simulations and during the construction of the slab specimens, respectively. Assessment of the formwork was verified according to the procedures prescribed by the ASTM C-192 [3] and ASTM C-470 [4] standards.

\section{DESIGN AND IMPLEMENTATION OF THE FORMWORK}

This section describes and discusses the design of the steel formwork required for casting concrete slabs with different dimensions. The reusable mold was designed to be used more than one time and constructed with several pieces. According to the Colombian standard NTC-5721 [5], which is equivalent to the European standard EN 14488-5 [6], the energy absorption capacity of concrete slabs should be assessed using specimens having $600 \mathrm{~mm}$ square section and thickness of $100 \mathrm{~mm}$. However, concrete slabs having the same square section but different side lengths (e.g., $500 \mathrm{~mm}$ and $400 \mathrm{~mm}$ ) are also required for research purposes. Different types of standard steel formworks are available in the market for beam-type specimens of $150 \mathrm{~mm} \times 150 \mathrm{~mm} \times 600 \mathrm{~mm}$, cube type with a side length of $150 \mathrm{~mm}$, cylinder type with a diameter of $150 \mathrm{~mm}$ and height of $300 \mathrm{~mm}$, or with a diameter of $100 \mathrm{~mm}$ and height of $200 \mathrm{~mm}$. However, it is uncommon to supply standard steel formworks for slab-type specimens, and formworks for slab-type specimens that can change the length of the slab. Given the interest in testing slabs of various sizes, we designed a steel formwork that allows casting slabs with side length of $600 \mathrm{~mm}, 500 \mathrm{~mm}$ and $400 \mathrm{~mm}$, and thickness of $100 \mathrm{~mm}$ and $75 \mathrm{~mm}$.

\section{A. Description of the formwork}

Molds for casting concrete specimens may be made of either a single piece or with a separate detachable base plate or base that is an integral part of the sidewall [4]. The steel formwork proposed in this study has nine or eleven pieces that are anchored with bolts. The reusable mold is provided with a base on the lower end at right angles to the axis of the square specimen. For casting of concrete slabs having side lengths of $600 \mathrm{~mm}, 500$ $\mathrm{mm}$ and $400 \mathrm{~mm}$, and thickness of $100 \mathrm{~mm}$ and 75 $\mathrm{mm}$, it is only necessary to set the steel formwork with a specific configuration of the pieces that comprise it. Fig. 1 shows the formwork configurations for the three sizes of concrete slab specimens. The layouts of the formwork were designed using the Solid Works tool (SolidWorks Corporation, 2013). The description of the steel formwork pieces is shown in Table 1. Additional plates were provided to firmly hold the base plate to the mold. 


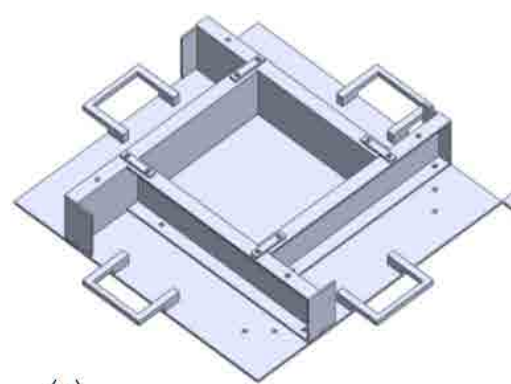

(a)

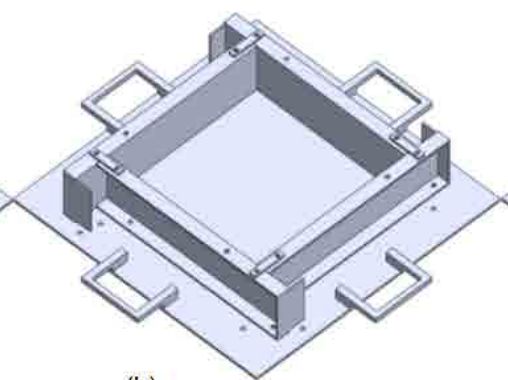

(b)

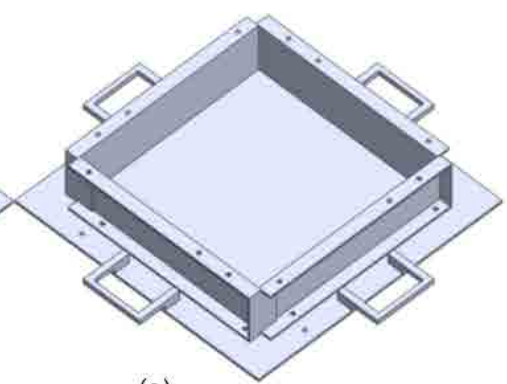

(c)

Fig. 1. Configuration of steel formwork for the three sizes of square concrete slabs: (a) $400 \mathrm{~mm}$, (b) $500 \mathrm{~mm}$, and (c) $600 \mathrm{~mm}$.

\section{TABLE 1}

ELEMENTS REQUIRED FOR SET UP

\begin{tabular}{|c|c|c|}
\hline Element & Dimensions & Description \\
\hline & $\begin{array}{c}\text { Flange: } \\
\text { Width: } 35 \mathrm{~mm} \\
\text { Thickness: } 4.8 \mathrm{~mm}\left(3 / 16^{\prime \prime}\right) \\
\text { Web: } \\
\text { Height: } 101.6 \mathrm{~mm}(4 ") \\
\text { Thickness: } 4.8 \mathrm{~mm}(3 / 16 ")\end{array}$ & $\begin{array}{l}\text { "C" steel, with holes for bolts of } 12.7 \\
\text { mm (1/2") }\end{array}$ \\
\hline & $\begin{array}{l}\text { Length: } 100 \mathrm{~mm} \\
\text { Width: } 20.2 \mathrm{~mm} \\
\text { Thickness: } 4.8 \mathrm{~mm}\end{array}$ & $\begin{array}{l}\text { H.R steel plate (hot rolled), ASTM } \\
\text { A-36 [8], with holes for bolts of } 12.7 \\
\text { mm (1/2") }\end{array}$ \\
\hline & $\begin{array}{c}\text { Length: } 820 \mathrm{~mm} \\
\text { Width: } 820 \mathrm{~mm} \\
\text { Thickness: } 4.8 \mathrm{~mm}(3 / 16 ")\end{array}$ & $\begin{array}{l}\text { H.R steel plate, ASTM A-36 [8], with } \\
\text { holes for bolts of } 12.7 \mathrm{~mm}(1 / 2 ")\end{array}$ \\
\hline
\end{tabular}

\section{B. Geometry and mechanical properties of the formwork}

Requirements of stiffness, strength, impermeability, and geometric tolerance were taken into account for designing and manufacturing the steel formwork. Regarding stiffness and strength, we selected dimensions and materials of the structural steel sections and sheets, in order to assure stability, restrain bending of the steel formwork during transportation, and preserve its dimensions and shape under all conditions of use. We selected a "C" structural steel section to prevent bending deformations to be greater than the geometrical tolerances specified by the NTC550 [7] and ASTM C-192 [3] standards. The selected structural section assures the restriction of excessive deformations on the steel formwork webs when casting the concrete or before removing the formwork.
Overall, the proposed formwork complies with the dimensions and tolerances specified by the method for which the specimens are required.

We assessed the mechanical performance of the steel formwork using the Solid Works tool (SolidWorks Corporation, 2013). This software estimates the strains and stresses caused by internal and external loads using the Finite Element Method (FEA). The FEM has become a robust modeling tool for assessing mechanical and civil engineering structures. In this study, a tetrahedral element was used to build a three-dimensional mesh (Fig. 2a). Geometry of the formwork was modeled using $10 \mathrm{~mm}$ size elements with linear properties. A torque moment of 0.0125 $\mathrm{N}-\mathrm{m}$ was applied to the bolted joints.

Performance of the proposed formwork was assessed using concrete specimens with three different side 
lengths of the square slabs $(600,500$ and $400 \mathrm{~mm})$ and two different thicknesses (100 and $75 \mathrm{~mm}$ ). Higher strains and stresses on the steel elements of the formwork were observed when casting the largest size slab specimen. The modeling results shown in this section are then related to that configuration. The simulation of vertical loads $\left(2.5 \mathrm{kN} / \mathrm{m}^{2}\right)$ on the steel formwork, using the Solid Works tool (SolidWorks Corporation, 2013), showed that the maximum displacement at the center of the formwork was approximately $0.2 \mathrm{~mm}$ for a particular concrete density of $25 \mathrm{kN} / \mathrm{m}^{3}$ (Fig. 2b). This displacement is significantly lower than the displacement limit specified by the NTC-550 [7] and ASTM-C192 [3]. For instance, those standards state that the maximum nominal variation should not exceed $3 \mathrm{~mm}$ of the nominal height of the formwork. In addition, the maximum tensile stress in the steel elements was lower than $25 \mathrm{MPa}$, which is roughly equivalent to the $10 \%$ of the material's yield strength $(250 \mathrm{MPa})$. Furthermore, no evidence of plastic deformations on joints surface, or higher shear stress in bolts were detected in the bolted joints of the FEA model.
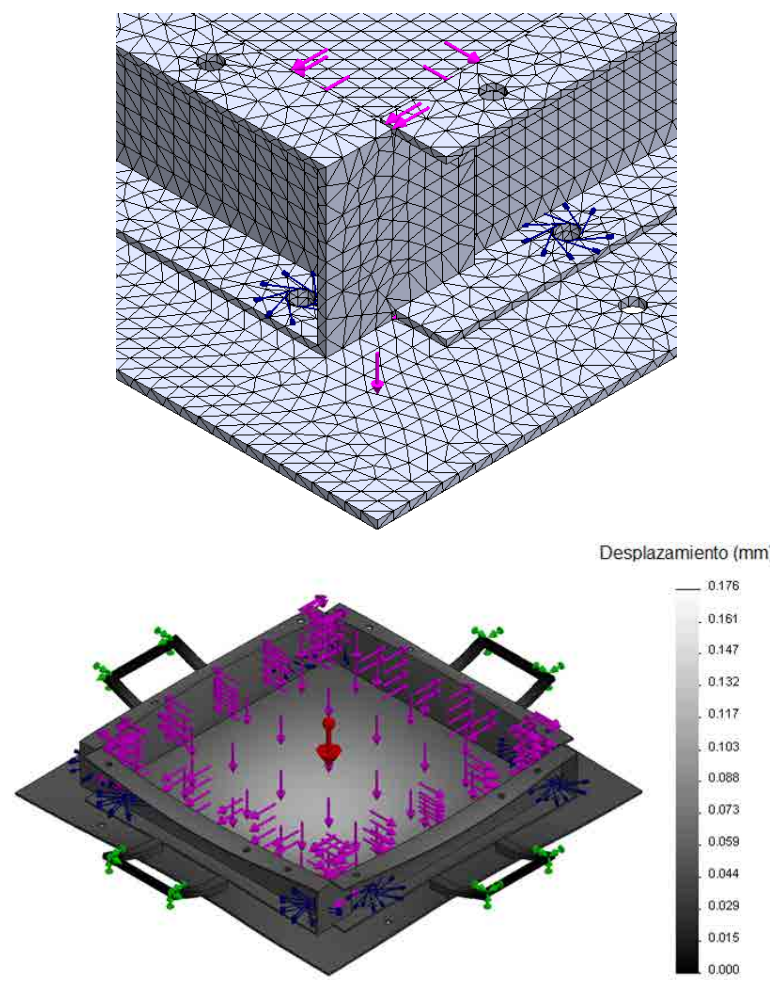

Fig. 2. Modeling of the steel formwork: (a) mesh, (b) simulation of vertical loads.
Regarding the impermeability properties, we considered the condition specified in the ASTM C-192 [3] standard, which states that molds for specimens that will be in contact with concrete should be made of steel, cast iron, or other nonabsorbent material, nonreactive with concrete containing Portland cement or other hydraulic cement that prevents absorption or water leak. Therefore, we choose the A36 steel regulated by the ASTM A-36 [8] standard as the base material. However, a suitable sealant, such as heavy grease, modeling clay, or microcrystalline wax, should be used where necessary to prevent leakage through the joints.

Regarding the geometry tolerance, the webs of the steel formwork are perpendicular to the base and machined to fix the webs, as defined by the NTC-550 [7] and ASTM C-192 [3] standards. Maximum variation from the nominal cross section did not exceed $2 \mathrm{~mm}$ as the maximum depth was $100 \mathrm{~mm}$. In addition, right angles were generated between the joints of the steel formwork pieces, and all the faces were smooth and free from indentations.

Regarding transportation, the empty steel formwork (without concrete) should be carried by two persons. However, in order to facilitate both the transportation of the steel formwork and the casting of the concrete slab, it must be carried by four persons. In addition, handles made of bars having $12.7 \mathrm{~mm}$ ( 0.5 in) in diameter were welded in the four sides of the formwork to facilitate transportation (Fig. 1). Regarding maintenance and practice suggested by the ASTM C-470 [4] standard, the mold for casting concrete specimens should be either coated or made of a material that will prevent adherence to the concrete. In this case, before using, the proposed reusable mold should be lightly coated with mineral oil or with a suitable nonreactive release material. Currently, the steel formwork is a patent pending in the Colombian Office of Industry and Commerce [9], and the cost of materials and fabrication is approximately USD \$ 200 .

\section{EXPERIMENTAL PROGRAM}

We built and tested concrete slabs reinforced with steel fibers or wire mesh, in order to show the results of our research addressed to propose a novel formwork. Our research aimed at assessing the dosage of steel fibers required in the concrete to attain in the slab a performance similar to that observed in the concrete 
slab reinforced with the conventional welded-wire mesh. The experimental program included testing ten slab specimens; of those, two had plain concrete (no flexural reinforcement, PC), two were reinforced with welded-wire mesh (WRC), and six had steel fiber reinforced concrete with dosages of $5 \mathrm{~kg} / \mathrm{m}^{3}$ (SFRC-5), $9 \mathrm{~kg} / \mathrm{m}^{3}$ (SFRC-9) and $18 \mathrm{~kg} / \mathrm{m}^{3}$ (SFRC18). As discussed in section 2.2, higher demands on steel elements of the formwork were observed when casting the largest size slab specimen; therefore, the experimental program was planned with that configuration. The results of the experimental program are described and discussed in this section.

\section{A. Type of concrete and reinforcement}

In this study, we used ready-mixed normal weight concrete with a nominal (design) compressive strength of $21 \mathrm{MPa}$ and a maximum aggregates size of $12 \mathrm{~mm}$. Dosages of materials per $\mathrm{m}^{3}$ of concrete were $283 \mathrm{~kg}$ of type I Portland cement, $71 \mathrm{~kg}$ of fly ash, $896 \mathrm{~kg}$ of gravel, $850 \mathrm{~kg}$ of sand, $219 \mathrm{~kg}$ of fresh water, and $2 \mathrm{~kg}$ of plasticizer additive.

Hooked-end steel fibers of $1.05 \mathrm{~mm}$ in diameter and $50 \mathrm{~mm}$ in length, aspect ratio of 48 , low carbon content, and tensile strength of $1115 \mathrm{MPa}$, were used. Fiber dosages of $5 \mathrm{~kg} / \mathrm{m}^{3}, 9 \mathrm{~kg} / \mathrm{m}^{3}$ and $18 \mathrm{~kg} / \mathrm{m}^{3}$ were included in the study. A single mesh with wires of 5

(a)

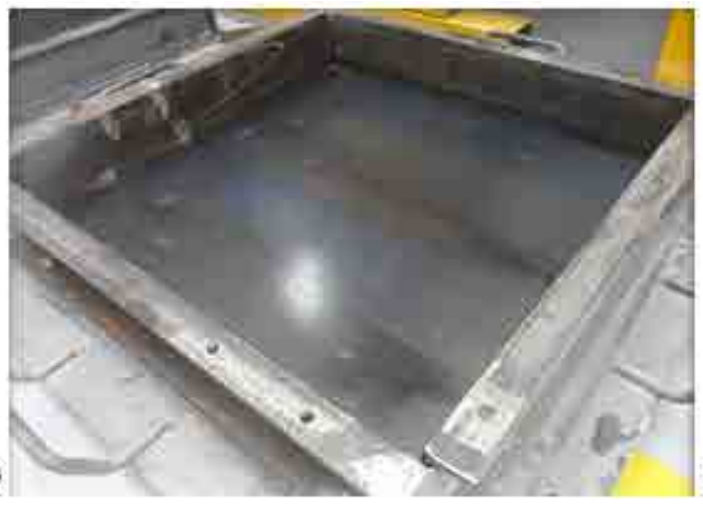

$\mathrm{mm}$ in diameter and a spacing of $150 \mathrm{~mm}$ was used in specimens reinforced with welded-wire mesh. The steel ratio approximately corresponds to the minimum steel ratio for temperature and shrinkage requirements prescribed by the ACI-318 (2014) [10] standard for slabs on ground. Compression, modulus of elasticity, splitting tensile, and flexural tests were carried out to assess the mechanical properties of concrete and steel fiber reinforced concrete. Stressstrain behavior of the wires was measured using coupon tests. Carrillo and Silva [11] measured the mechanical properties of concrete and reinforcement.

\section{B. Preparation of specimens}

Considering the requirements specified by the NTC5721 [5] standard, the steel formwork was assembled using the configuration where the length side of the square specimens was $600 \mathrm{~mm}$. To facilitate removing the formwork, a light coating of oil was applied on the inner webs of the steel formwork. We used either steel fibers randomly dispersed or welded-wire mesh to reinforce the slabs specimens (Fig. 3). When weldedwire mesh was used, strain gauges were glued to the wires. In order to verify the performance of the steel formwork, we used three methods for concrete filling: a manual method using a shovel, a mechanical method using a wheelbarrow, and a mechanical method using a special bucket for concrete pouring. Form vibration was applied through a rubber hammer.

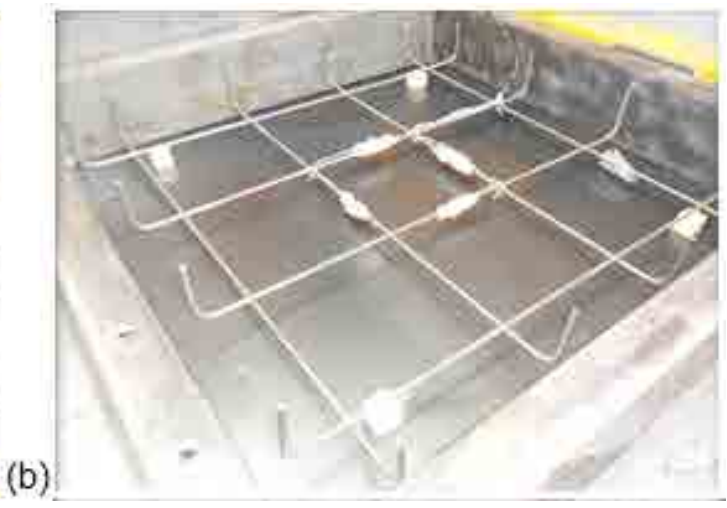

Fig. 3. Steel formwork for concrete slabs before casting: (a) concrete reinforced with steel fibers, (b) concrete reinforced with welded-wire mesh.

\section{Setup of energy absorption tests}

The energy absorption capacity of the concrete slabs was assessed using specimens with $600 \mathrm{~mm}$ square section and thickness of $100 \mathrm{~mm}$. The test procedure followed the Colombian standard NTC-5721 [5], which is equivalent to the European standard EN 14488-5 [6]. Quasi-static vertical tests were carried out using a load frame having a $100 \mathrm{kN}$ capacity actuator, and a special device for measuring the 
vertical displacement at multiple locations during the test [12] (Fig. 4b). The concrete slab specimen was supported on the four ends of a square steel frame. The quasi-static test was displacement-controlled, and the loading rate was $1.5 \mathrm{~mm} / \mathrm{min}$. Details of the test procedure and performance of concrete slabs are reported and discussed by Carrillo et al. [13] .

\section{RESULTS AND DISCUSSION}

This section discusses the main results in terms of specimen casting, formwork removal, and tests conducted on the formwork, such as water leakage, resistance to damage, and dimensional stability.

\section{A. Specimen casting and formwork removal}

Casting of concrete slabs, using the three different pouring methods listed in section 3.2, produced different levels of stresses on the steel formwork. The method that caused the greatest impact was pouring the concrete using the bucket. However, this impact did not cause any damage or distortion in the original geometry of the steel formwork. Molds did not leak water at the time of use. After two days of casting, the specimens within the steel form were moved to a stock site. Removing the formwork was very easy, due to the rapid disassembling of the steel formwork pieces, and the light coating of oil applied before casting the specimens. Optimal results of the concrete specimens were observed when removing the formwork because no cracks on the slab surfaces were generated during transportation of the specimens. In addition, neither the steel formwork nor the specimen suffered any modification in their geometry. Regarding the cleaning process, it was observed that the material selected to build the formwork pieces allowed to easily remove the excess of concrete.
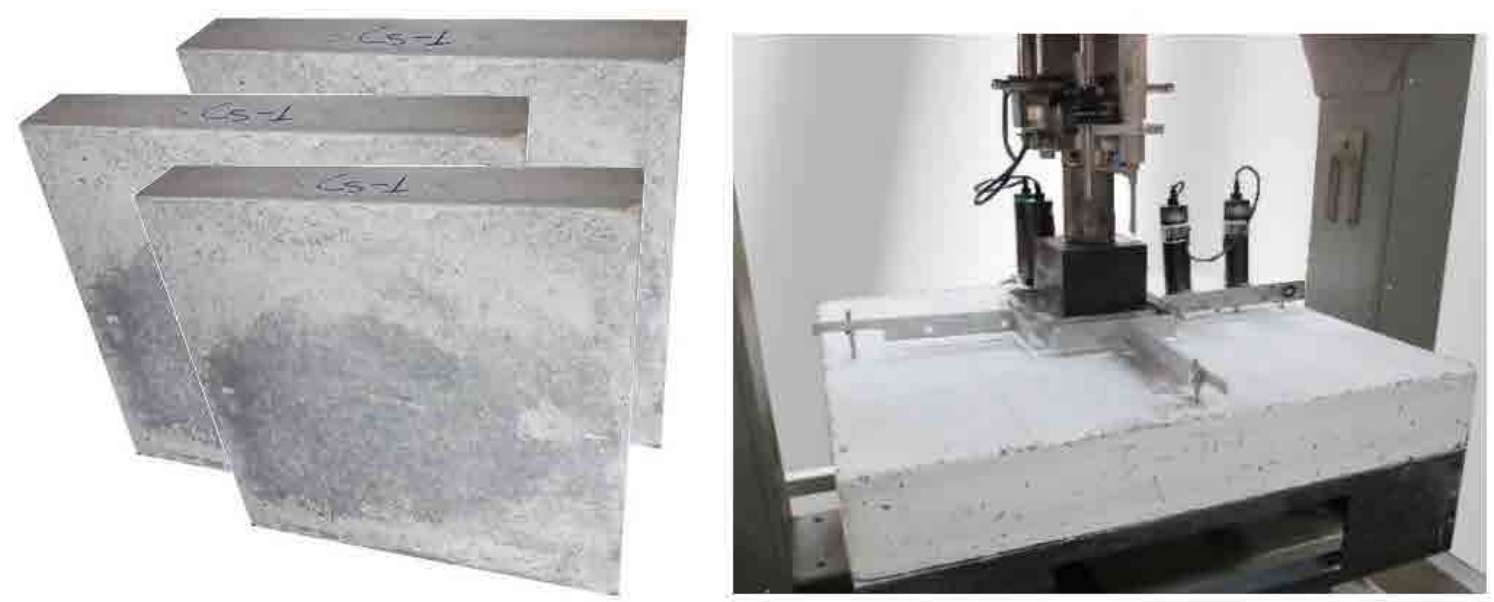

Fig. 4. Results: (a) concrete slabs after casting, (b) setup for mechanical testing.

\section{B. Testing the formwork}

According to the ASTM C-470 [4] standards, metal reusable molds should be tested for water leakage, resistance to damage, and dimensional stability after 50 uses. In order to ensure the molds complied with these specifications, we randomly tested three reusable molds. To test for water leakage, first, the reusable molds were assembled with the sealant to be used, and then, were filled with water to a depth of 90 to $95 \%$ of their nominal height. As mentioned before, the molds were subjected to tapping and jarring, which is considered to represent what typically occurs when specimens are cast, in accordance with the applicable provision of the ASTM C-192 [3] standard. One hour after tapping, examination of molds demonstrated no visible leakage. Regarding resistance to damage and dimensional stability, Carrillo et al. [13] verified the apparent damage and dimensional requirements of the three reusable molds after 50 uses, and found that the molds complied with these specifications because no failure and dimensional instability were observed when the proposed mold was used for casting slabs and panels. These specimens were tested to characterize the mechanical properties and the flexural performance of several mixes of steel fiber reinforced concrete (SFRC). The results demonstrated that the formwork did not affect the geometrical and initial mechanical 
properties of the specimens. Flexural performance of some slab specimens is shown in Fig. 5.

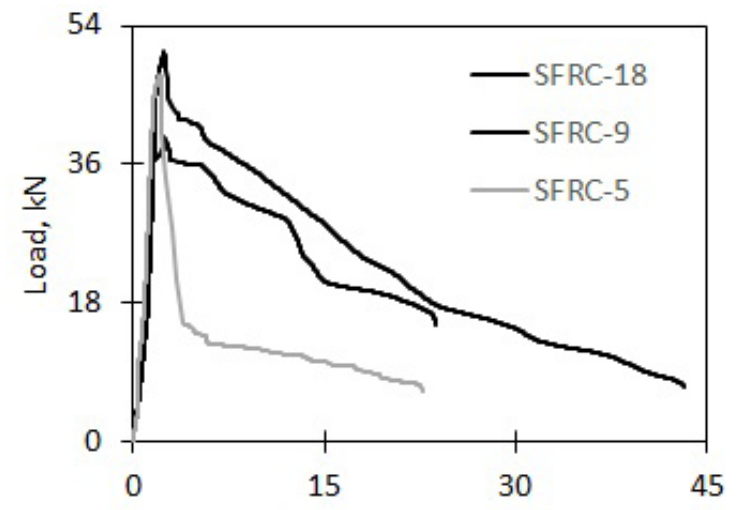

(a)

Deflection, $\mathrm{mm}$

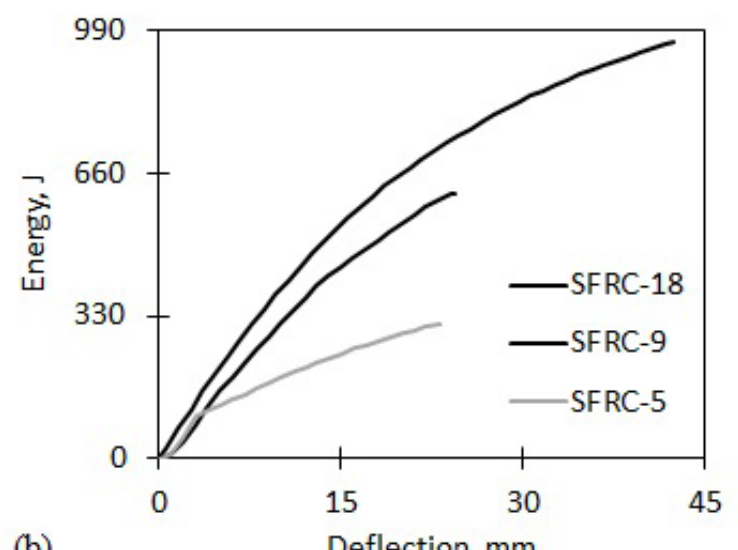

(b)

Fig. 5. Flexural performance of SFRC slabs: (a) load-deflection curves, (b) energy-deflection curves.

\section{Conclusions}

This paper proposed a reusable and reconfigurable formwork to facilitate and increase the reliability of the results obtained in experimental programs of materials and structures. The assessment of the formwork performance was carried out through the analysis of numerical and experimental results that were obtained from simulations and during the construction of the slab specimens, respectively. For instance, the advantages of the formwork were verified from observations during the construction of concrete slabs reinforced with steel fibers or welded-wire mesh. Transportation of the formwork and removal of the specimen was suitably and safely performed, demonstrating ease of usage, time saving, and good surface finishing of the concrete specimens. The reusable formwork is made of a non-absorptive material, holds its shape right after casting the concrete, and avoids purchasing a greater number of formworks with particular dimensions, which increases costs and the need for storage space. We recommend using formwork accessories for attaining different thicknesses of the concrete slab specimens.

\section{ACKNOWLedgments}

The authors gratefully acknowledge to Vicerrectoría de Investigaciones at the Universidad Militar Nueva Granada (UMNG, Colombia) for financing the research project IMP-ING-2130.

\section{Author's Contribution}

Julian Carrillo and Felipe Riveros designed the formwork. Felipe Riveros and Luis Llano improved the mechanical design of the formwork. Felipe Riveros tested the specimens. Julian Carrillo and Luis Llano analyzed the test results and verified the performance of the formwork.

\section{REFERENCES}

[1] M. Ruíz, B. Blachowsky, and B. Spencer, "Use of wireless sensors for assessing modal parameters," in XVIII National Conference of Structural Engineering, Mexican Society of Structural Engineering - SMIE, Acapulco, Guerrero-Mexico, 2012.

[2] K. Hossain, S. Gurbani, and M. Anwar, "Performance evaluation of engineered Newark concrete forming tubes for construction," Technical Report, Ryerson University, 2013, $51 \mathrm{pp}$.

[3] ASTM, "Standard practice for making and curing concrete test specimens in the laboratory, ASTM C-192," American Society for Testing Materials, 2016, 8 pp.

[4] ASTM, "Standard specification for molds for forming concrete tests cylinders vertically, ASTM C-470," American Society for Testing Materials, 2015, 5 pp.

[5] ICONTEC, "Test method for energy absorption capacity of fiber reinforced concrete: NTC 5721," Instituto Colombiano de Normas Técnicas, 2009.

[6] EFNARC, "Testing sprayed concrete - Part 5: Determination of energy absorption capacity of fiber reinforced slab specimens: EN-14488-5," European 
Federation for specialist construction chemicals and concrete systems, 2000.

[7] ICONTEC, "Elaboración y curado de especímenes de concreto en obra: NTC 550," Instituto Colombiano de Normas Técnicas, 2000.

[8] ASTM, "Standard specification for carbon structural steel: ASTM A-36," American Society for Testing Materials, 2014, 4 pp.

[9] J. Carrillo, F. Riveros, and L. Llano, "Molde configurable para elementos de sección transversal cuadrada," (en proceso de patente, Superintendencia de Industria y Comercio de Colombia, SIC), 2017.

[10] ACI Committee 318, "Building code requirements for structural concrete and commentary (ACI 31814)," American Concrete Institute, Farmington Hills, MI, 2014.
[11] J. Carrillo, and D. Silva, "Flexural tests of concrete slabs-on-ground reinforced with steel fibers," Revista Ingeniería, Investigación y Tecnología, vol. 17 (3), pp. 317-330, Jul. 2016. DOI: http://doi.org/10.1016/j. riit.2016.07.003.

[12] J. Carrillo, F. Riveros, and L. Llano, "Dispositivo para sujeción de múltiples transductores de desplazamiento en ensayos de losas de concreto," Revista Ingeniería Mecánica: Tecnología y Desarrollo, vol. 6 (2), pp. 113-319, 2015.

[13] J. Carrillo, D. Silva, and M. Sánchez, "Performance of concrete slabs-on-ground reinforced with weldedwire mesh or steel fibers," Revista Ingeniería, Investigación y Tecnología, vol. 17 (4), pp. 499-510, 2016. DOI: http://doi.org/10.1016/j.riit.2016.11.009. 